\title{
Macro-fungi Community of Lake Ol Bolossat Basin and Associated Riparian Ecosystems in Central, Kenya
}

\author{
Mary Nyawira Muchane ${ }^{1, \text { *, Kelvin Maina Waithaka }{ }^{1} \text {, Taita Terer }}$ \\ ${ }^{1}$ Botany Department, National Museums of Kenya, Nairobi, Kenya \\ ${ }^{2}$ Centre for Biodiversity Department, National Museums of Kenya, Nairobi, Kenya \\ Email address: \\ mmurethi@yahoo.com (M. N. Muchane),mnyawira@museums.or.ke (M. N. Muchane) \\ ${ }^{*}$ Corresponding author
}

\section{To cite this article:}

Mary Nyawira Muchane, Kelvin Maina Waithaka, Taita Terer. Macro-fungi Community of Lake Ol Bolossat Basin and Associated Riparian Ecosystems in Central, Kenya. International Journal of Natural Resource Ecology and Management. Vol. 6, No. 1, 2021, pp. 6-15. doi: 10.11648/j.ijnrem.20210601.13

Received: February 17, 2021; Accepted: March 3, 2021; Published: March 12, 2021

\begin{abstract}
Lake OlBolossat, an important wetland in Central Kenya highland currently threatened by anthropogenic activities. In order to conserve biodiversity in this Lake Ecosystem and associated habitats understanding abundance and diversity of different taxa is needed. This study documented macro-fungi diversity of Lake Ol Bolossat basin and its associated riparian ecosystems. The survey revealed 35 macrofungi species distributed across 21 families. Species in family Polyporaceae and Agaricaceae (mainly the puffball) dominated the Lake ecosystems. Woodrotters species (50\%) dominated the ecosystem followed by ectomycorrhiza (17\%) and cow-dung dwellers (15\%). Termite cultivated species and soil dwellers had the lowest representation (9\%). Macro-fungi density, species richness and diversity was significantly low in natural grassland and forest remnants compared to introduced and exotic woodlots. Only three species of macrofungi (Termitomyces microcarpus, Ramariopsis kunzei and Datronia mollis) were documented in natural forests remnants. Natural grassland around the lake was mainly dominated by Termitomyces, Lycoperdon, Panaeolus (cowdung), Psilocybe and Agrocybe species (cowdung). Ectomycorrhiza species (Laccaria bicolor, Pisolithus arrhizus, Suillus granulatus, Scleroderma citrinum) dominated introduced and exotic Eucalyptus, Pinus and Acacia mearnsii plantation. This study has revealed wide range of macro-fungi community in Lake Ol Bolossat basin, and adverse effect of degradation on native macro-fungi community. The negative implication of losing macrofungi diversity along Lake OlBolossat ecosystem is discussed.
\end{abstract}

Keywords: Conservation, Degradation, Diversity, Land Use, Mushrooms

\section{Introduction}

Lake Ol Bolossat is an important wetland in Central Kenya occurring in Nyandarua County with both salty and freshwater. The lake lies at average altitude of 2340 metres above the sea level making it highest altitude lake in East Africa and an important stopover for migratory birds from Australia, Europe and Egypt. It serves the Ewaso Nyiro River catchment which supports human communities, wildlife and livestock in Samburu, Isiolo, Laikipia and Garissa counties. Despite its small size $\left(43 \mathrm{~km}^{2}\right)$ the lake provides unique and important habitat for birds (including migratory birds), insects, fish, reptiles mammals and plant species. However, over the past year, the lake has been experiencing massive shrinking following unsustainable human activities such as over grazing, pollution, illegal settlement on riparian land and quarrying activities. Area under cultivation has increased tremendously following rapid rise in commercial and subsistence agriculture while forested land and floodplains have decreased following increases in upstream deforestation. Deforestation and cultivation of floodplains has in return increased levels of land degradation evidenced by high levels of soil erosion, overgrazing, burning and encroachment onto riparian and forest reserved [1]. This has negatively influenced to Lake primary productivity and ecosystem services accrued. Although the lake was gazetted 
as a wetland protected area by Kenyan Government, very little rehabilitation has been done on its riparian land. Yet healthy riparian area is key in protecting Lake Basin ecosystem services such as water quality as well as protecting land from lake waters [2]. There is an urgent need, to step up management and conservation interventions in order to rehabilitate degraded areas. Since riparian ecosystems are extremely sensitive to changes in environmental conditions, understanding its biodiversity status can help monitor degradation levels and advice on effective rehabilitation and conservation methods. Although macro-fungi community plays very vital role in sustaining stable terrestrial and wetland ecosystems, and are early indicators of environmental change, very little is known about macro-fungi community in Lake Olbolosat.

Macro-fungi (mushrooms) are fungi species with visible fruiting bodies and invisible extensive belowground mycelia [3]. There are approximately 110-140 thousand macro-fungi species distributed worldwide [4-6]. In their natural conditions, macrofungi community play key roles in sustaining plant community by regulating nutrient cycling processes through decomposition of dead plant and animal material, supplying nutrients to plants and providing food for insects, small mammals and soil microbes [7]. Macro-fungi also contribute greatly to local livelihoods through provision of food and income through development and growth of dyes, pharmaceuticals, organic acids, hormones, food, animal feeds and beverage processing industries [8]. Macro-fungi in their natural conditions are sensitive to changes in climate (temperature, humidity), soil quality and plant community [9], and can therefore be an early indicators of land degradation [10]. Losses of macro-fungal community are shown to precede decline of the respective plant community by $5-10$ years $[11,12]$. Therefore understanding macro-fungi diversity has great potential in predicting the fate of natural ecosystems under different levels of stresses.

This study focused on understanding the macro-fungi diversity in riparian zones around Lake Ol'Boosat with aim of revealing the macro-fungi diversity and possible role in environmental and ecosystem services. Such information is key in development of sustainable livelihoods and alleviation of increased rural poverty within Lake Ol'Boosat Ecosystem.

\section{Materials \& Methods}

\subsection{Study Site}

This work was conducted in Lake Olbolosat (Figure 1). The region is situated around a latitude of $0^{\circ} 09^{\prime} \mathrm{S}$ and longitude $36^{\circ} 26^{\prime} \mathrm{E}$ in Nyandarua county in the central part of Kenya. The lake has a surface area of about $43 \mathrm{~km}^{2}$ and lies at an average altitude of about $2340 \mathrm{~m}$ in a wedge shaped rift valley floor, known as Ongata Pusipusi. The region has temperatures of $10^{\circ}$ and $28^{\circ} \mathrm{C}$ and mean annual rainfall of
$980 \mathrm{~mm}$. The rainfall is bimodal, with long peaks between April and June and the shorter peaks between October and November. The climate is generally sub-humid. The riparian area surrounding Lake Olbolosat is approximately $4800 \mathrm{~km}^{2}$, encompassing Nyandarua Ranges, Satima Escarpment and Ndundori Hills. The water from the basin flows northwards through Thomson's fall into the northern part of Ewaso Nyiro River. Generally, the region of Lake Olbolosat has a history of colonial settlements when the major land-uses were large scale livestock rearing and crop production. In the recent past however, the area has gone through considerable land-use changes under the national settlement fund trustees, resulting into significant land subdivision and fragmentation, especially after 1993. Presently, the majority of people living in the area are small scale farmers who grow subsistent crops and rear domestic livestock on land parcels ranging from 0.5 to 8 acres. The human population density of the area is approximately 202 per $\mathrm{km}^{2}$.

\subsection{Experimental Design}

Olobosat lake ecosystem varies dramatically, according to site elevations. In this study, 6 sampling blocks (10km apart) were identified, three in the East and 3 in the West (Figure 1, Table 1). In each block, two transect of $1 \mathrm{~km}, 5 \mathrm{~km}$ apart were laid down. The first plot was installed near the lake shoreside of wetland area and the last plot was installed at settled areas with the cultivated land. In each transect four plots (H1-H4, $20 \mathrm{~m} \times 20 \mathrm{~m}$ ), each $250 \mathrm{~m}$ apart, were demarcated for sampling of macrofungi. The $\mathrm{H} 1$ plot was lowest water point which was partially submerged in lake water, while other three plots were distributed along the wetland slope with increased elevation (Table 1). H2 was mainly in natural grassland $250 \mathrm{~m}$ away from the shore while $\mathrm{H} 3$ and $\mathrm{H} 4$ were in farm land either in cultivated soil (maize crop) or in Eucalyptus woodlot (Eucalyptus polybractea, Eucalyptus saligna) or Acacia mearnsii tree plantation. The 3 remaining natural forested ecosystems were also sampled to provide baseline data. The experiment had a total of 48 plots (6 blocks, 2 transects and 4 plots mainly falling in various land uses)

Table 1. Sampling blocks, transects and plots in Lake Olbolosat Ecosystem.

\begin{tabular}{llll}
\hline Block & Local name & Transects & Plots per block \\
\hline \multirow{2}{*}{ Block1 } & Mairo Inya & T1 & 4 \\
& (Kanguyo) & T2 & 4 \\
Block2 & Ngurumo (Iria-ini) & T1 & 4 \\
& & T2 & 4 \\
Block3 & Gakoe (Karima) & T1 & 4 \\
& & T2 & 4 \\
Block4 & Mukindu (Karandi) & T1 & 4 \\
& & T2 & 4 \\
Block5 & Fuleni (Kanguu) & T1 & 4 \\
& & T2 & 4 \\
Block6 & Kianjata (Kibathi) & T1 & 4 \\
\multirow{2}{*}{ Total number of plots sampled } & T2 & 4 \\
\hline
\end{tabular}




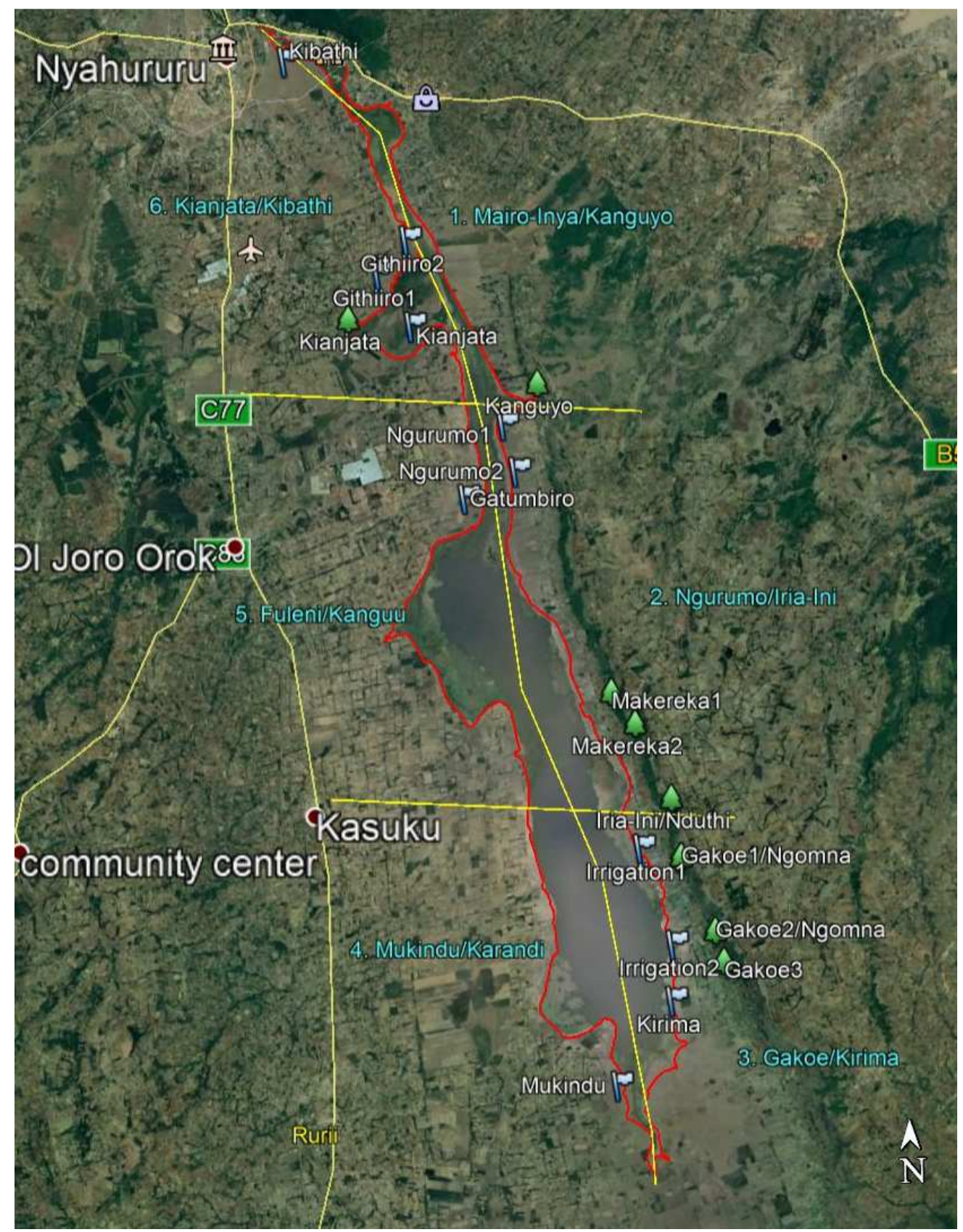

Figure 1. Lake Ol'Bolossat basin showing the main Geographic features.

\subsection{Collection and Morphological Characterization of Macro-fungi Species}

In each plot, encountered macro-fungi were photographed in-situ and all features such as phenology, smell, habitat, colour, nature of substrate and associated plant species were recorded. Numbers of fruiting bodies encountered in each sampling plots were also recorded. Few representative fruit bodies of each collection were transported to Mycology laboratory, National Museums of Kenya for herbarium collection and microscopic analysis whenever necessary. In the laboratory, the collected macro-fungi identification was based on macro-micromophological features by comparison using coloured field guide books, monographs of colored mushrooms such as [13-19] and internet facility. Some of the mushrooms after freshly observation were oven dried $\left(40^{\circ} \mathrm{C}\right)$ and deposited at the mycological herbarium of the National Museums of Kenya.

\subsection{Data Analysis}

Species density, richness and diversity were assessed for each land use. Shannon-Wiener diversity index (Nolan \& Callahan 2006) was used because it favors neither rare nor common species disproportionately while counting all species according to their frequency thus considering weighting to each species exactly by its frequency in the sample. Paleontological Statistics (PAST) Software was used 
[20]. Analysis of variance (ANOVA) was performed for density, species richness and diversity index to find significant effect of land use on macro-fungi using SPSS Version 18 (SPSS, 2009). Turkey's test was applied for comparison of means when appropriate. All the data are being subjected to normality test to confirm whether they meets ANOVA assumptions before analysis

\section{Results}

\subsection{Macro-fungi Community}

A total number of 35 macro-fungi species from Basidiomycota and Ascomycota division distributed across 18 families and 27 genera were documented in Lake Olbolosat ecosystem. Macro-fungi species observed were dominated by lignicolous (wood inhabiting fungi) which formed $48 \%$ of total macrofungi species (Table 1, Figure 2). They were followed by humicolous (humus inhabiting mushrooms) fungi comprising of $33 \%$ of total species. Mycorrhiza and termite cultivated fungi were least with $12 \%$ and $\& 7 \%$ of total species. Polyporaceae and Xylariaceae species had the highest number of representation with 4 species each followed by Lyophyllaceae and Hymenochaetaceae with three species each (Figure 3). Other families had 2 or less species represented (Figure 3, Plate 1). Species accumulation curve showing the number of macrofungi species encountered within the ecosystem did not reach an asymptote indicating that the 6 blocks sampled did not adequately sample all the species in the Lake Olbolosat (Figure 4).

Table 2. Macro-fungi species observed across Lake Olbolosat

\begin{tabular}{|c|c|c|c|c|c|c|c|c|c|c|}
\hline Family & Genus & Species & Author & Substrate & $\frac{\text { Mairo-Inya }}{\text { (Block 1) }}$ & $\begin{array}{l}\text { Ngurumo } \\
\text { (Block 2) }\end{array}$ & $\begin{array}{l}\text { Gakoe } \\
\text { (Block 3) }\end{array}$ & $\begin{array}{l}\text { Mukindu } \\
\text { (Block 4) }\end{array}$ & $\begin{array}{l}\text { Fuleni } \\
\text { (Block 5) }\end{array}$ & $\begin{array}{r}\text { Kianjata } \\
\text { (Block 6) }\end{array}$ \\
\hline Agaricaceae & Lycoperdon & spl-4 & & $\mathrm{S}$ & & + & + & + & & \\
\hline Agaricaceae & Macrolepiota & $S p$ & & $\mathrm{~S}$ & & + & & & & \\
\hline Bolbitiaceae & Conocybe & $S p$ & & $\mathrm{C}$ & & & + & + & & \\
\hline Clavariaceae & Ramariopsis & kunzei & (Fr.) Corner & $\mathrm{S}$ & & + & & & & \\
\hline Geastraceae & Geastrum & $S p$ & & S & & & & & + & \\
\hline Hydnangiaceae & Laccaria & bicolor & (Maire) P. D. Orton & ECM & & & + & & & \\
\hline Hydnangiaceae & Laccaria & $S p$ & & ECM & & & + & + & + & + \\
\hline $\begin{array}{l}\text { Hymenochaetacea } \\
\text { e }\end{array}$ & Fuscoporia & gilva & $\begin{array}{l}\text { (Schwein.) T. Wagner \& M. } \\
\text { Fisch }\end{array}$ & W & + & + & + & + & & \\
\hline $\begin{array}{l}\text { Hymenochaetacea } \\
\text { e }\end{array}$ & Fuscoporia & $S p$ & & W & & + & & & & \\
\hline Hymenogastraceae & Psilocybe & cubensis & (Earle) Singer & $\mathrm{C}$ & & & & + & & \\
\hline Lyophyllaceae & Termitomyces & microcarpus & (Berk. \& Broome) R. Heim & $\mathrm{T}$ & & + & & + & & \\
\hline Lyophyllaceae & Termitomyces & umkowaan & $\begin{array}{l}\text { (Cooke \& Massee) D. A. } \\
\text { Reid }\end{array}$ & $\mathrm{T}$ & & + & & & & \\
\hline Lyophyllaceae & Termitomyces & Spl & & $\mathrm{T}$ & & + & + & + & & \\
\hline Marasmiaceae & Marasmius & $S p$ & & $\mathrm{C}$ & & & & + & & \\
\hline Meruliaceae & Aurantiporus & $S p$ & & W & & + & & & & \\
\hline Nidulariaceae & Cyathus & $S p$ & & W & & & + & & & \\
\hline Polyporaceae & Datronia & Mollis & Björn S & W & & + & & & & \\
\hline Polyporaceae & Lentinus & $S p$ & & W & & + & & & & \\
\hline Polyporaceae & Polyporus & arcularius & (Batsch) Fries & W & & + & & & & \\
\hline Polyporaceae & Trametes & versicolor & (L.) Lloyd & W & + & + & & + & + & + \\
\hline Psathyrellaceae & Panaeolus & antillarum & (Fr.) Dennis & $\mathrm{C}$ & & & + & & & \\
\hline Psathyrellaceae & Panaeolus & $s p$. & & $\mathrm{C}$ & & & + & & & \\
\hline Psathyrellaceae & Coprinellus & micaceus & $\begin{array}{l}\text { (Bull.:Fr.) Vilgalys, Hopple \& } \\
\text { Jacq. Johnson }\end{array}$ & W & & & + & & & \\
\hline Rhizopogonaceae & Rhizopogon & $S p$ & & ECM & & & + & & & \\
\hline Schizophyllaceae & Schizophyllum & commune & Bernard Spragg & W & & & & & & + \\
\hline Sclerodermataceae & Scleroderma & citrinum & Pers. & ECM & & + & + & & & \\
\hline Sclerodermataceae & Pisolithus & arrhizus & (Scop.) Rauschert & ECM & + & & & + & & \\
\hline Stereaceae & Stereum & histurm & (Willd.) Pers & W & + & & + & + & + & \\
\hline Stereaceae & Stereum & $S p$ & & W & & & & & & \\
\hline Strophariaceae & Gymnopilus & junonius & (Fr.) P. D. Orton & W & + & & + & & & \\
\hline Suillaceae & Suillus & granulatus & (L.) Roussel & ECM & & + & & & & \\
\hline Xylariacea & Daldinia & concentrica & (Bolton) Cesati \& de Notaris & W & + & & & & & \\
\hline Xylariacea & Daldinia & $S p$ & & W & & + & & & & \\
\hline Xylariaceae & Kretzschmaria & $S p$ & & W & & + & & & & \\
\hline Xylariaceae & Xylaria & polymorpha & (Pers.) Grev & W & & & + & & & \\
\hline
\end{tabular}

‘+’: Present; ، ': Absent; T: Termite Mound; W: Decaying wood; S: Soil; ECM: Ectomycorrhiza; C: Decomposing dung. 


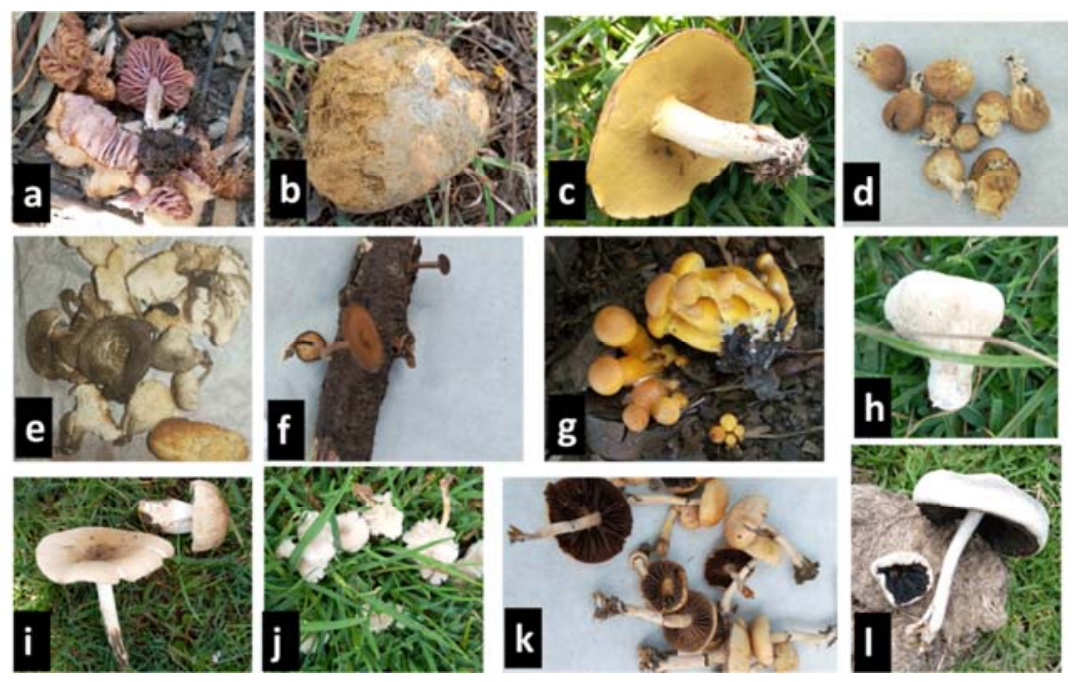

Plate 1. Some macrofungi fruit bodies collected Lake Olbolosat (a) Laccaria bicolor, (b) Pisolithus arrhizus, (c) Suillus granulatus, (d) Scleroderma citrinum, (e) Letinus sp. (f) Auricularia polytrica, (g) Gymnopilus junonius, (h) Lycoperdon sp. (i) Termitomyces umkowaan (J) Termitomyces microcarpus, (k) Psilocybe cubensis and (l) Panaeolus antillarum.

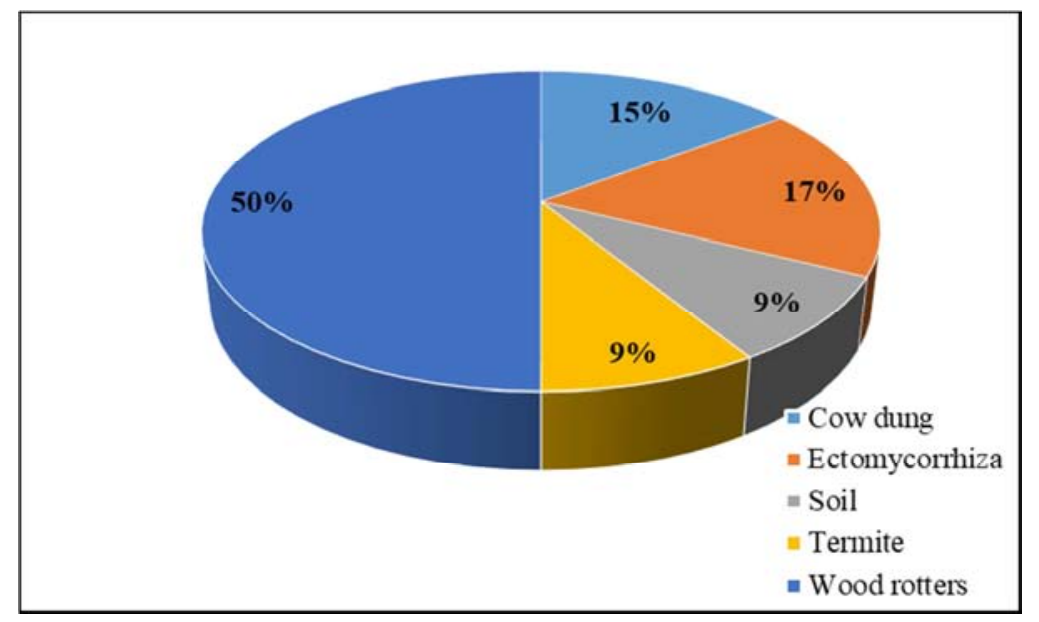

Figure 2. Quantitative distribution of macrofungi in Lake Olbolosat based on substrate.

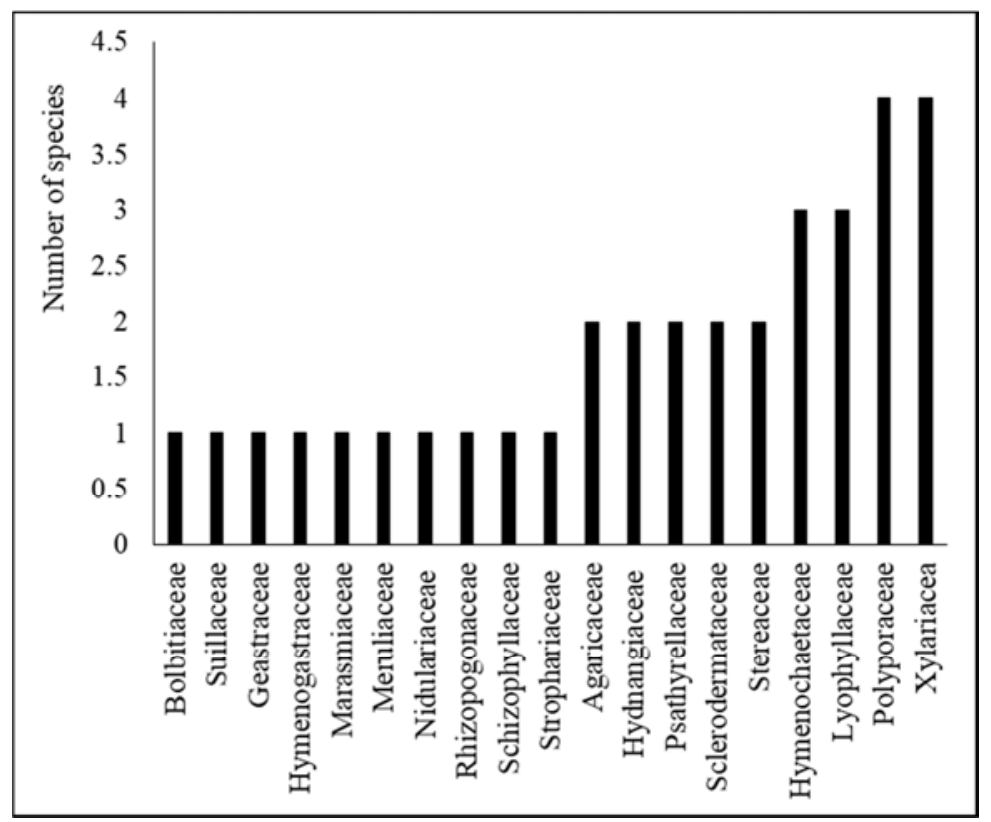

Figure 3. Number of species in different families encountered in the Lake Olbolosat, Kenya 


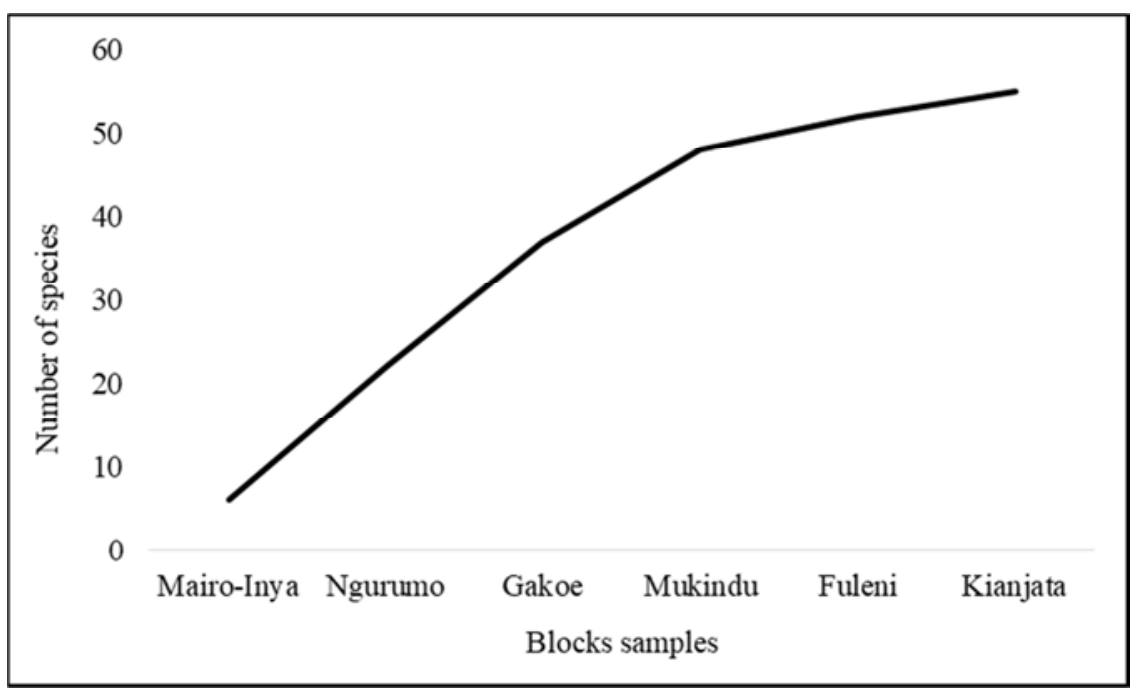

Figure 4. Cummulative Curve of macrofungi in Lake Olobolosat, Kenya

\subsection{Effect of Land Use on Macro-fungi Diversity}

A total of 35 (average number of 5.6 species per block) species were recorded. Block, land use and interaction of block and land use significantly $(\mathrm{p}<0.05)$ influenced macrofungi species richness, and diversity (shannon $\mathrm{H}$ index) and density (Table 3). Blocks away from urban centres (Block 3 and 4) had the highest macro-fungi species richness, density and diversity (Table 3). In nearly all blocks, macrofungi species density, species richness and diversity were highest in areas with Eucalyptus woodlots (Table 3). In blocks away from urban areas (block 3 and 4), macro-fungi species richness, density and diversity was also relatively high in Eucalyptus woodlots and farmland. In blocks near urban areas, macrofungi species richness, density and diversity was extremely low in areas near the lake (Table 3). Though macro-fungi species richness, density and diversity tended to be high in Eucalyptus woodrots in blocks near urban centers, macro-fungi species richness, density and diversity were not significantly different across different land uses (Table 3). Natural grassland recorded the lowest levels of macro-fungi species in all blocks.

Table 3. Effect of land use and blocks on macro-fungi community in Lake Olbolosat. Woodlots with Eucalyptus tree species, Farmland dominated by maize crops, grassland and regions near the lake region.

\begin{tabular}{|c|c|c|c|c|}
\hline & & Species Richness & Species Density & Shannon (H) Diversity Index \\
\hline & & - - & ea------------------- & ------ \\
\hline \multirow[t]{4}{*}{ Block 1} & Lake & $0.0(0.0) \mathrm{d}$ & $0.0(0.0) \mathrm{b}$ & $0.0(0.0) \mathrm{c}$ \\
\hline & Grassland & $1.0(1.0) \mathrm{cd}$ & $14.0(7.2) \mathrm{b}$ & $0.4(0.1) \mathrm{b}$ \\
\hline & Eucalyptus & $2.0(1.0) \mathrm{bc}$ & $179.0(50.0) \mathrm{a}$ & $0.4(0.1) b$ \\
\hline & Farmland & $0.0(0.0) \mathrm{dc}$ & $0.0(0.0)$ & $0.0(0.0) \mathrm{c}$ \\
\hline \multirow[t]{4}{*}{ Block 2} & Lake & $1.0(0.0) \mathrm{c}$ & $58.0(34.2) \mathrm{b}$ & $0.0(0.0) \mathrm{c}$ \\
\hline & Grassland & $0.5(0.2) \mathrm{dc}$ & $0.5(0.2) \mathrm{b}$ & $0.0(0.0) \mathrm{c}$ \\
\hline & Eucalyptus & $2.0(0.0) \mathrm{bc}$ & $14.5(100.2) \mathrm{b}$ & $0.3(0.1) b c$ \\
\hline & Farmland & $0.5(0.2) \mathrm{cd}$ & $7.0(5.2) \mathrm{b}$ & $0.0(0.0) \mathrm{c}$ \\
\hline \multirow[t]{4}{*}{ Block 3} & Lake & $0.5(0.2) \mathrm{cd}$ & $0.5(0.3) b$ & $0.0(0.0) \mathrm{c}$ \\
\hline & Grassland & $1.5(0.5) b c$ & $29.5(8.0) b$ & $0.2(0.1) \mathrm{c}$ \\
\hline & Eucalyptus & $3.5(1.5) b$ & $16.0(14.0) \mathrm{a}$ & $1.1(0.3) \mathrm{a}$ \\
\hline & Farmland & $4.5(2.5) \mathrm{b}$ & $181.5(40.0) \mathrm{a}$ & $0.8(0.2) \mathrm{ab}$ \\
\hline \multirow[t]{4}{*}{ Block 4} & Lake & $8.5(1.5) \mathrm{a}$ & $335.5(43.5) \mathrm{a}$ & $1.1(0.2) \mathrm{a}$ \\
\hline & Grassland & $1.3(0.9) \mathrm{cd}$ & $31.7(27.7) \mathrm{a}$ & $0.2(0.1) \mathrm{c}$ \\
\hline & Eucalyptus & $10.0(1.1) \mathrm{a}$ & $379.0(60.0) \mathrm{a}$ & $0.4(0.1) \mathrm{b}$ \\
\hline & Farmland & $0.5(0.3) \mathrm{cd}$ & $4.0(3.0) \mathrm{b}$ & $0.0(0.0) \mathrm{c}$ \\
\hline \multirow[t]{4}{*}{ Block 5} & Lake & $0.0(0.0) \mathrm{d}$ & $0.0(0.0) \mathrm{b}$ & $0.0(0.0) \mathrm{c}$ \\
\hline & Grassland & $0.0(0.0) \mathrm{d}$ & $0.0(0.0) \mathrm{b}$ & $0.0(0.0) \mathrm{c}$ \\
\hline & Eucalyptus & $3.0(0.1) b c$ & $167.5(75.2) \mathrm{a}$ & $0.3(0.1) b c$ \\
\hline & Farmland & $0.0(0.0) \mathrm{d}$ & $0.0(0.0) \mathrm{b}$ & $0.0(0.0) \mathrm{c}$ \\
\hline \multirow[t]{4}{*}{ Block 6} & Lake & $0.0(0.0) \mathrm{d}$ & $0.0(0.0) b$ & $0.0(0.0) \mathrm{c}$ \\
\hline & Grassland & $0.0(0.0) \mathrm{d}$ & $0.0(0.0) \mathrm{b}$ & $0.0(0.0) \mathrm{c}$ \\
\hline & Eucalyptus & $1.5(0.5) b c$ & $5.5(4.5) \mathrm{b}$ & $0.3(0.1) b c$ \\
\hline & Farmland & $0.0(0.0) \mathrm{d}$ & $0.0(0.0) \mathrm{b}$ & $0.0(0.0) \mathrm{c}$ \\
\hline \multirow[t]{3}{*}{ ANOVA } & Block & $6.83(0.00)$ & $2.36(0.07)$ & $4.08(0.008)$ \\
\hline & Land use & $7.12(0.001)$ & $2.75(0.05)$ & $6.17(0.003)$ \\
\hline & Block $x$ Land use & $4.26(0.00)$ & $2.10(0.04)$ & $3.35(0.002)$ \\
\hline
\end{tabular}




\subsection{Effect of Degradation on Macrofungi Diversity}

To assess effect of degradation on macro-fungi community, we compared species richness, density and diversity from different land uses with that in natural forest remnants. Contrary to our expectation, species richness, density and diversity of macro-fungi in natural forest was significantly lower $(p<0.05$ in all cases $)$ than that in Eucalyptus woodlots and significantly higher than that in natural grassland (Figure 5a-f). Species richness, density and diversity of macro-fungi in natural forest was two or three times lower than that in Eucalyptus woodlot. Species richness, density and diversity of macro-fungi in natural forest was not significantly different $(p>0.05)$ from that in farmland and areas near the lake region (data not shown).

\section{Discussions}

Lake Olbolosat ecosystem has a diverse macro fungi assemblage, although the species density and richness was lower than expected. Lake Olbolosat ecosystem being a high altitude ecosystems with rain forest characteristic, high macro-fungi diversity equivalent to that of Aberdares forest were expected [21]. However, our study has revealed only 35 species similar to studies conducted in savannah ecosystem
(Maasai Mara) and Coast region [9, 22]. This difference could be attributed to sampling season and level of habitat degradation. Macro-fungi (mushrooms) have short life cycles (1-20 days) and their occurrences is favored by wet (rainy) seasons [23]. Our sampling season coincided with on-set of rainy period, and we could have missed mid and late fruiting species. The species in this ecosystem increased linearly with sampling effort (Figure 5), suggesting not all species were captured and macro-fungi diversity in this ecosystem could be higher than captured. This work however provides vital information for understanding macro-fungi community of Lake Olbolosat and forms baseline information for further research in this area. Additionally, this is the first report of macro-fungi in Lake Olbolosat ecosystem. The data provides important information that can be used for development of management and conservation strategies which can be used to aid in monitoring macro-fungi community. At the same time, diversity of macro-fungi is known to vary, depending on micro habitats among other ecological and environmental factors. This suggests a more detailed survey in future taking into consideration various ecological and environmental factors that influence macro-fungi diversity to complement our data. Detailed monitoring studies are also necessary to document the sprouting period of each fungal species after the on-set of rainy season.
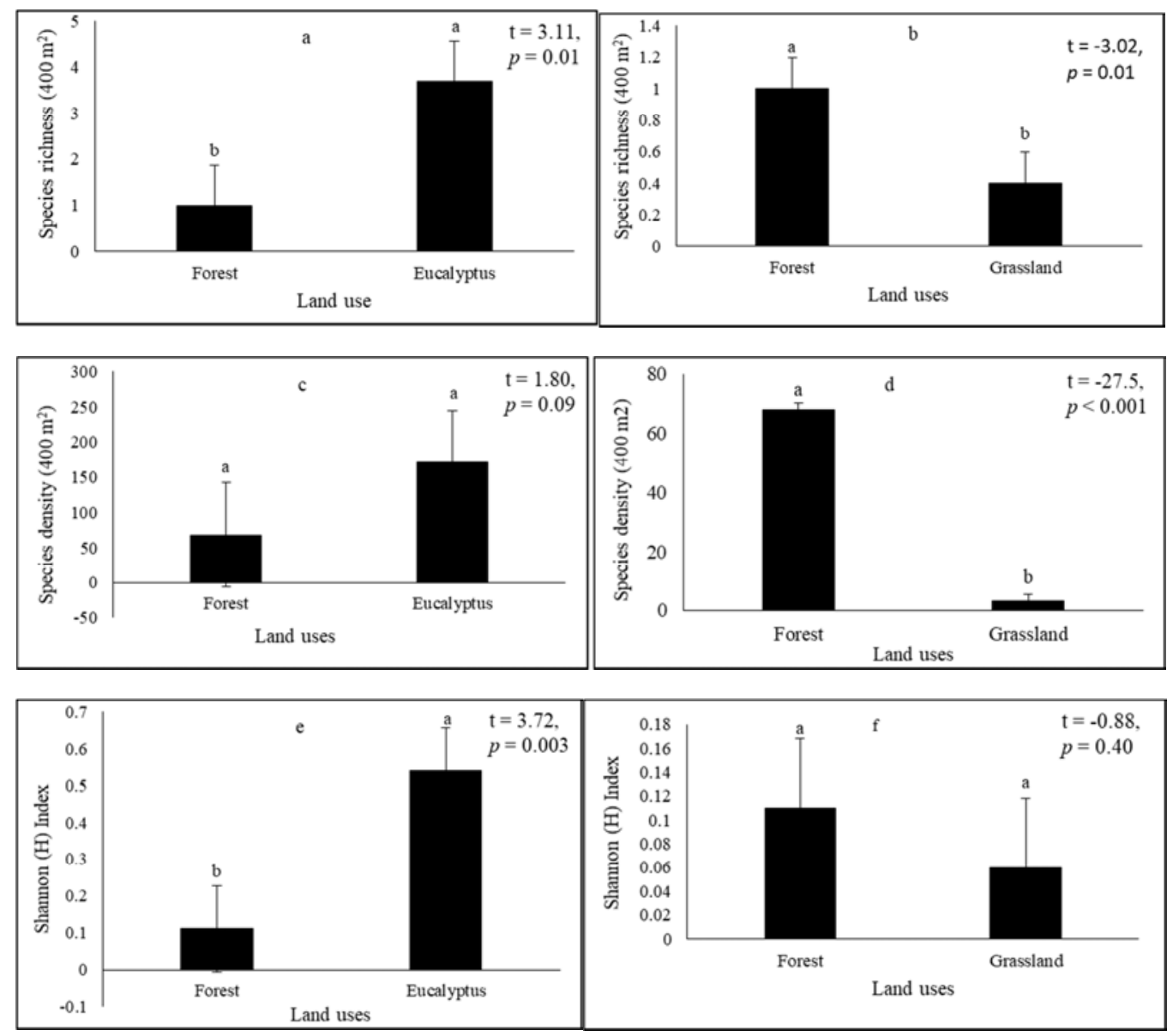

Figure 5. Impacts of degradation on macrofungi community in Lake Olbolosat, Kenya. 
Woodrotting fungi especially from Polyporaceae and Stereaceae family dominated the ecosystem. This was expected since species from Polyporaceae and Stereaceae families are perennial polypores and experience minimal effect to seasonality or annual variation compared to fresh humicolous fungi. Hard external upper fruiting body of these woodrotters have deeply rooted vegetative mycelium and long-narrow hymenial tubes that make them remains saturated even in dry environmental conditions [24]. Surprisingly majority of these woodrotting species were found associated with introduced exotic tree species such as Eucalyptus, Pinus and Acacia mearnsii species. Agaricaceae species were mainly dominated by puffballs from Lycoperdon and Clavatia genera growing in humified organic matter mainly in grassland and few in exotic tree plantations. Although species from Agaricaceae are known not to associate with a given habitat [25], puffballs recorded in this region were mainly from grassland. Ectomycorrhiza fungi (ECM) species were relatively high than expected, and their diversity could be linked to introduction of exotic Eucalyptus, Pinus and Acacia mearnsii species. Although diversity of ECM species in this ecosystem is introduced, some of these ECM species have found wide usage among local community. Pisolithus arrhizus is currently being used for harvesting of honey. The spores from this species are known to cause temporary loss of sensation or awareness for bees enabling farmers harvest honey without protective gadgets. Elsewhere the species is also being used in dye production industry and is thought to have anticancer properties.

Termitomyces species (family Lyophyllaceae) were unique species found growing naturally mainly in grassland, with a few species collected in farms. Members of Termitomyces live symbiotically with termites of the family Termitidae and are exclusively found in certain regions of Africa and Asia [9, 26]. In Kenya, geographical patterns of fungus-growing termites and their symbionts have not been studied systematically though reports of their occurrences in Savannah ecosystems of Maasai Mara, Tsavo and highland of western and central Kenya have been shown [9, 27]. Termitomyces species were mainly found in grassland adjacent to the lake. Apart from assisting proliferation of termite host species, Termitomyces species in this region are economically valuable natural resource serving as an alternative to plant- and animal-derived foods and medicine. Many species of Termitomyces are used as food by many Africa community. They are also used for medicinal purpose since they contain antioxidants, immunomodulators, antitumors and antimicrobials properties [28]. According to the local communities, Termitomyces species harvested from wild are cooked as stew for ugali (maize porridge) dishes. Although we recorded only three species during this survey, our communication with local communities described over six species. Being a unique and economic species found in this ecosystem, there is need to protect remaining natural grassland and forest ecosystems to preserve these species.
Human activities are threat to both fungus-growing termites and symbionts mushroom species, hence need for conservation strategies. Crop cultivation affects termites' garden, which consequently leads to destruction of Termitomyces species.

Natural ecosystems (forests, grassland) are known to support wide range of mushroom assemblage, diversity, abundance and species richness due to abundance of wood substrates from different plant species [21]. Contrary to our expectations macrofungi diversity in this ecosystem were significantly high in introduced and exotic Eucalyptus woodlots than in natural forest and natural grassland. Macrofungi diversity in cultivated farmland was not significantly different from that of natural grassland and forest. Surprisingly, only three species were encountered in the remaining natural forest ecosystems. These results contrast many studies showing showing high macrofungi community in natural ecosystems compared to cultivated ecosystem [9, 21]. This can be linked to destruction of favorable macro- and micro- climate (humid conditions, temperature), high levels of anthropogenic interferences, low litter fall and degradable wood substrates and presence of open gaps through degradation. In this study, the remaining natural forest remnants were highly degraded with evidences of tree cutting for charcoal and firewood. Local community in this region solely rely on remaining natural forest for energy. Exotic tree species planted are mainly Eucalyptus species and are used for post and timber production. Only a few plantation of Acacia mearnsii are planted for firewood. Overgrazing was also evident with animals trails observed all over the forests, natural grassland and within lake shore. Overgrazing is known to reduce plant growth, plant cover, below and above productivity through continuous harvesting of nutrients, through grazing of palatable grasses and herbaceous plants. Ground trampling further destroys sprouting macro-fungi, resulting to negative implication to macrofungi diversity. There was also evidence of low plant diversity associated with low litter and organic matter inputs which are key contributors to macro-fungi community [29]. It was also evident that, the remaining natural forest ecosystems are located in rocky places and along river valleys where farming is relatively hard. Hence the soils in these natural forested ecosystems are still young, and rocks outcrops are currently undergoing weathering. This means soil potential of retaining adequate soil organic matter to support macrofungi community is limited. This is an indication that, local community occupied land potential for agriculture leaving the remnants forest in areas unsuitable for agriculture.

In addition, our results suggest replacement of naturally macro-fungi in this ecosystem with exotic fungi. Introduction of exotic tree species for example have led to introduction of ectomycorrhiza species. Surprisingly, woodrotters were also found in growing in association Eucalyptus, Pinus and Acacia mearnsii trees species. Similar results were reported showing changes in structure and composition of natural vegetation, and replacement of native grasses and shrubs species with 
plant species like Grewia species, Scutia species, Rhus nalatensis and Buddleya polystachya [30]. Human activities like uncontrolled felling of trees, deliberate fires and cultivation on steep land are cited as major drivers of habitat degradation in entire ecosystem [30,31]. We have also shown urbanization as major threat of macrofungi community in this ecosystem. Our results shows low macrofungi density, species richness and diversity in blocks near urban centres (block 6, 5 and 1,2 ) in comparison to those away from town (block three and four). Effect of urbanization on macrofungi is not well documented. However soil contamination in the form of heavy metals, soil eutrophication, habitat conversion and modification into built environments have negative effect to local fungal communities $[32,33]$. In this study urban areas were associated with high infrastructural development, urban settlement, quarrying and pollution of ecosystem by high human population. Cultivation in the shores of the lake as well as land sub-division into small plots of a quarter an acre was evident. Such unsustainable human activities are expected to have detrimental effect on macro-fungi community.

The consequences of losing native macrofungi community and replacement with new community in sustainability of ecological services supported by fungi is not yet well known. Although initial losses native species may produce only small effects in an ecosystem, the losses may significantly affect capacity of an ecosystems adapt to changing environments in particular climate change. Macrofungi community play important role in sustaining plant community through nutrient cycling, myco-remediation of polluted areas and mitigation of adverse effect of climate change through increased soil carbon storage. They also provide an alternative livelihood options (mushroom farming) thus reducing poverty among local community. Losses of macrofungi community means losses of these benefits. Due to privatization of land along the Lake Olbolosat Ecosystem only few restoration of degraded programs have been implemented. Most of these programs are implemented without taking into consideration the role of fungi community. There is assumption that fungi community will self-re-establish following tree establishment. However some fungi species may take long duration to self-establish and this may affect long-term sustainability of restoration programs. There is need to assist fungi back in degraded sites through inoculation of tree seedling, development and implementation of fungi-specific management and conservation strategies. Although there is no case of macrofungi invasion in Kenya, proliferation of exotic species in new environment region may increase due to lack of natural predators and pests. This suggest need for studies on influences introduced fungi species may have on native species and implication they have on sustainability of ecosystem services in Lake Olbolosat ecosystems.

\section{Conclusion}

Surprisingly our results revealed high diversity of macrofungi in introduced-exotic trees woodlots compared to natural grassland and forested ecosystems. Documented macro-fungi species were further shown to be associated with introducedexotic tree species, suggesting replacement of major native macro-fungi species. Despite high level of degradation, natural forests and grassland ecosystems support wide range of Termitomyces and Puffball species, and provide vital ecosystems which can be used to rediscover original macrofungi community of this ecosystem. We recommend a detailed study in remaining natural forested and grassland ecosystems to reveal macro-fungi community that may have not sprouted during the current sampling period. We further recommend studies on long term effect of introduced species on sustainability of ecosystem services. Such kind of research will help in recognition of early abnormal invasion of species and aid in development of sustainable management. We further recommend protection of natural forest and grassland ecosystems from further degradation so that they can be used as biodiversity natural reserve for Lake Olbolosat ecosystem. The natural reserve can serve as live gene-bank and seed sources for original mushroom as well as other botanical biodiversity. Use of compatible conservation strategies that are compatible with biodiversity and livelihood such as mushroom farming are necessary.

\section{Acknowledgements}

This work was financed by Birdlife International and Critical Ecosystem Partnership Fund (CEPF)

\section{References}

[1] Mugo, G. (2011). Land use and its effect on biodiversity in the lake Ol'Bolossat basin, Nyandarua, Kenya.

[2] Njomo, G. K. (2018). Soil and water conservation measures and challenges in Kenya; A review. International Journal of Agronomy and Agricultural Research (IJAAR), 12 (6): 116145 .

[3] Chang, S. T. \& Miles, P. G. (1992) Mushroom biology, New discipline. The Mycologist, 6: 64-65.

[4] Hawksworth, D. L. (2001) The magnitude of fungal diversity: the 1.5 million species estimate revisited. Mycological research. 105 (12), 1422-1432.

[5] Mueller, M. G., Bills, F. G. \& Foste, S. M. (2005). Biodiversity of fungi inventory and monitoring method. San Diego: Elsevier Academic Press.

[6] Hawksworth, D. L. (2012) Global species numbers of fungi: are tropical studies and molecular approaches contributing to a more robust estimate?. Biodiversity Conservation 21, 24252433, https://doi.org/10.1007/s10531-012-0335-x

[7] Ambrosio, E. L., Lancellotti, E., Brotzu, R. \& Salch, H. (2015). Assessment of macrofungal diversity in a Silver Fir plantation in Sardinia (Italy) using a standardized sampling procedure. Italian Journal of Mycology, 44 (1), 1-1.

[8] Boa, E. (2004). Wild edible fungi a global overview of their use and importance to people, Non-Wood Forest Products 17, Fao Press, Rome, Italy. 
[9] Tibuhwa, D. D., Muchane, M. N., Masiga, C. W., Mugoya, C. \& Muchai, M. (2011). An inventory of macro-fungi and their diversity in the serengeti-masai mara ecosystem, Tanzania and Kenya. Journal of Biological Sciences, 11, 399-410.

[10] Laganà, A., Salerni, E., Barluzzi, C \& Perini, C. (2002). Macrofungi as long-term indicators of forest health and management in Central Italy. Cryptogamie Mycologie 23, 350 .

[11] Arnnolds, E. (1991). Decline of ectomycorrhizal fungi in Europe. Agriculture Ecosystems \& Environment 35 (2-3): 209-244.

[12] Jakucs, W. (1988). Ecological approach to forest decay in Hungary. Ambio 170: 241-272.

[13] Largent, D. L. \& Their, D. H. (1984). How to Identify Mushrooms to Genus II: Field Identification of Genera. Mad River Press Inc., Califonia, Pg 32.

[14] Largent, L. D. (1986). How to Identify Mushrooms to Genus I: Macroscopic Features. Mad River Press Inc., Eureka, USA.

[15] Kirk, P. M., Cannon, P. F., David, J. C. \& Stalfers, J. A. (2001). Ainsworth and Bisby's Dictionary of the Fungi. 9th Edn., CAB International, Wallingford, UK

[16] Harkonen, M., Niemela, T. \& Mwasumbi, L. (1995). Edible Mushrooms of Tanzania. Yliopistopaino, Tanzania, ISBN-13: 9789514569623, Pages: 92.

[17] Harkonen, M., Niemela, T. \& Mwasumbi, L. (2003). Tanzanian Mushrooms: Edible, Harmful and Other Fungi. Botanical Museum, Finnish Museum of Natural History, Tanzania, ISBN-13: 9789521014208, Pages: 200.

[18] Mueller, M. G., Bills, F. J. \& Foster, S. M. (2004). Biodiversity of Fungi: Inventorying and Monitoring Methods. Elsevier Academic Press, New York, USA, Pages 128-172.

[19] Lincoff, G. H. (2005). Field Guide to Mushrooms. National Audubon Society, New York, USA., Pages 926.

[20] Hammer, Ø., Harper, D. T. \& Ryan, P. D. (2001). PAST: Paleontological Statistics Software Package for Education and Data Analysis. Palaeontologia Electronica 4 (1): 9pp.

[21] Njuguini, S., Muchane, M. N., Wachira, P., Okoth, S., Muchai, M. \& Saado, H. (2018). Effects of Land Use on the Diversity of Macrofungi in Kereita Forest Kikuyu Escarpment, Kenya. Current Research in Environmental \& Applied Mycology, 8, 10.5943/cream/8.

[22] Gateri, M. W., Ndungu, U. B., Muriuki, A., Rauwl, V. \& Kabacia, S. (2014). Collection, identification and morphological characterization of indigenous mushrooms in coastal Kenya. In Proceedings of 8th International Conference on Mushroom Biology and Mushroom Products (ICMBMP8), I \& II: 17-23. ICAR-Directorate of Mushroom Research.

[23] Packham, J. M., May, T. W., Brown, M. J., Wardlaw, T. J. \& Mills, A. K. (2002). Macrofungal diversity and community ecology in mature and regrowth wet eucalypt forest in Tasmania: A multivariate study. Austrian Ecology, 27, 149161.

[24] Priyamvada, H., Akila, M., Singh, R. K., Ravikrishna, R., Verma, R. S., Philip, L., Marathe, R. R., Sahu, L. K., Sudheer, K. P. \& Gunthe, S. S. (2017). Terrestrial macrofungal diversity from the tropical dry evergreen biome of southern India and its potential role in aerobiology. PLoS ONE, 12 (1), $1-12$.

[25] Uzun, Y. (2010). Macrofungal diversity of Ardahan and Igdir province (Turkey). International Journal of Botany, 6, 11-20.

[26] Singer, R. (1986). The Agaricales in Morden taxonomy, 980 pp.

[27] Vesala, R., Niskanen, T., Liimatainen, K., Boga, H., Pellikka, P. \& Rikkinen, J. (2017). Diversity of fungus - growing termites (Macrotermes) and their fungal symbionts (Termitomyces) in the semiarid Tsavo Ecosystem, Kenya. Biotropica 49 (3), 402-412.

[28] Hsieh, H. M. \& Ju, Y. M. (2018). Medicinal components in Termitomyces mushrooms. Applied Microbiology and Biotechnology, 102, 10.1007/s00253-018-8991-8.

[29] Sousa, F. P., Ferreira, T. O., Mendonça, E. S., Romero, R. E. \& Oliveira, J. B. (2012). Carbon and nitrogen in degraded Brazilian semi-arid soils undergoing desertification. Agriculture, Ecosystems \& Environment, 148: 11-21, https://doi.org/10.1016/j.agee.2011.11.009.

[30] Okumu, J. (2017). Lake Ol Bolossat synthesis report. East African Wild Life Society (EAWLS) https://eawildlife.org/Docs/LAKE\%20OL\%20BOLOSSAT\% 20SYNTHESIS\%20REPORT.PDF

[31] National Environment Management Authority, NEMA. (2007). Lake Ol-Bolossat Management Plan 2008-2013. Kenya Wetlands Forum. Nairobi, Kenya.

[32] Newbound, M., Mccarthya, M. A. \& Lebelc, T. (2010). Fungi and the urban environment: A review. Landscape and Urban Planning, 96: 138-145, doi: 10.1016/j.landurbplan.2010.04.005.

[33] Guerrero, JJ., Banares, EN., General, MA and Imperial, JT. (2020). Rapid survey of macro-fungi within an urban forest fragment in Bicol, eastern Philippines. - Österr. Z. Pilzk. 28: $37-43$. 